\title{
English Test Performance and The Contextual Factors On Tertiary Education
}

\author{
Gandy Griselda Quijano-Zavala' $\mathbf{8}(\mathbb{D})$, Rosa Adriana May-Meléndez ${ }^{2} \mathbf{D}$ and Magdalena Apasra \\ Bandala-Garcés ${ }^{3} \mathbf{8}$ (D) \\ ${ }^{123}$ Professor, English Language Program, Department of Education and Humanities, Universidad Autónoma del Carmen, Mexico \\ $\triangle$ Corresponding Author: Gandy Griselda Quijano-Zavala, E-mail: gquijano@pampano.unacar.com.mx
}

\section{ARTICLE INFORMATION ABSTRACT}

Received: August 08, 2021

Accepted: September 10, 2021

Volume: 3

Issue: 10

DOI: $10.32996 /$ jeltal.2021.3.10.1

\section{KEYWORDS}

Performance, English, context, factors, tertiary education, gender, socio-economic status, private, public, Mexico
Even though English has remained an important element at different levels of education, studies in different parts of the world indicate that proficiency and performance in English can be a challenge. A specific example is the case of Mexico. Learning English has been stated as important in the Mexican education system for decades, yet, Mexico has held low proficiency in English for a long time. This study forms part of a larger mixed-methodology study of an institution of higher education in southeast Mexico. This paper aims to explore the descriptive results of 882 firstyear university students on an English institutional test to study their language performance and the salient contextual factors. The test results were analyzed using descriptive statistics and correlations using SPSS, version 21. The results show that students' English test performance is mostly low. Independent sample t-tests indicate that while gender is not an influencing factor on test performance, higher exam scores are associated with the type of high school education.

\section{Introduction}

English is a global language, and it is used for communication among speakers of other languages. In fact, most learners of English outnumber native English speakers (Ur, 2012). The rapid growth of English as an international language has led to an increasing interest to be proficient in English. The access to communication and information by means of English as an international language is undeniable. Millions of students around the world study English at different levels of education and for different purposes; for example, many would like to engage in a cultural exchange, others wish to escalate the work ladder, while many others must study the language at school as part of the education system. Yet, while there are learners who seem to learn it with no apparent effort, there are learners who face difficulties to be proficient in a second language (L2).

The literature indicates that factors related to language learning can, on the one hand, be internal such as language transfer and other linguistic issues, and on the other hand, external factors, which include social aspects such as age, gender, social class, ethnic identity, and social context (Ellis,1994). In fact, many studies performed in different countries point out the importance of context in language performance (Główka, 2014; Kormos \& Kiddle, 2013; Mahmud, 2010; Rind, 2015). Contextual factors noticeably impact students' language learning and interrelate to language performance. It is, therefore, important to explore contexts to understand learners' realities and point out potential problems that may arise at different stages of learning.

Context remains an essential aspect of language learning even when English is considered an international language. The experiences behind learning the language vary depending on where it is learned and how it is learned. Every education system around the world designs its own policies with regard to the teaching-learning process. For instance, many schools use English as the Medium of Instruction (EMI) for all subjects while in some other scenarios, English is learned as one more subject in school. In other words, it is studied, but rarely practiced. Dearden (2014) performed a study on EMI, where 55 countries participated. The results highlight two important aspects in this education practice: 1) EMI is more used at the tertiary level of education and 2) it is more prevalent at private institutions. The extent of the use of English in the classroom modifies learners'

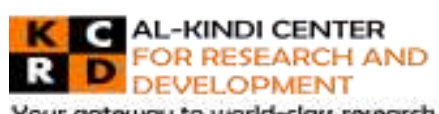

Your goteway to world-class research

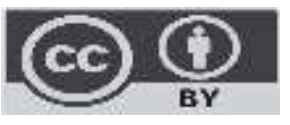

Published by Al-Kindi Center for Research and Development, United Kingdom. Copyright (c) the author(s). This open access article is distributed under a Creative Commons Attribution (CC-BY) 4.0 license 
linguistic outputs. For this reason, it is advisable to explore the practices about the teaching-learning experience of English in different parts of the world.

As mentioned earlier, external factors are important for language learning scenarios; they should be viewed as a vehicle to describe language performance. To improve English language learning in any context, it becomes necessary to explore and describe the contextual factors that can influence test results. This article addresses gender and socio-economic status by means of analyzing the differences in test results of first-year university students. Gender differences in English language teaching point out that the use of strategies and performance (Ariyani, Rusminto \& Setiyadi, 2018; Namaziandost, Abedi \& Nasri, 2019) are different between genders. Also, recent studies that have explored the learning of English in foreign scenarios point out a marked gap (Alipour, 2018; Pervaiz, Rana, Bashir \& Batool, 2021) between social classes. These differences adhere to social context.

This article follows a quantitative approach as it addresses the descriptive results of diagnostic institutional test performance of first-year university students in a southeast Mexican university regarding gender and public and private high school education. This last factor has been considered as representative of social status; yet, it would be needed to explore it further in future studies. This paper presents a summary of the literature regarding studies that discuss contextual factors and language learning performance followed by the methodology section, the results and a discussion. Its aim is to shed light on the relationship between test performance and contextual factors leading to language learning.

\section{Literature Review}

Regardless of the reason to embark on the process of learning English, achieving language domain continues to be controversial in language classrooms around the world. As previously mentioned, factors can shape language learning in different scenarios. Different studies have mentioned some specific contextual factors in learning English as a foreign language, but here two factors are explored: 1) Gender differences in achievement and 2) Influence of socio-economic status on achievement.

General differences on how females and males communicate have been widely studied (Tannen, 1990; Tannen, 2017) as well as the differences in language learning. For instance, Rind (2015) discusses the importance of gender identity in English language teaching as it shapes the learners' experiences. To illustrate, males seem to be more active in speaking than females. But females prefer to express themselves through writing in the language classroom (Mahmud, 2010). Additionally, in a longitudinal study with secondary school participants, Karthigeyan and Nirmala (2012) found that although performance in English was average, girls' academic achievement in English was higher than boys. In a study on social factors that impact the learning of English of secondary school students, Główka (2014) also found that females achieved significantly better results than males. These studies support that females performed better than boys. Yet, Bidin and Jusoff (2009) performed a study with middle school students from boarding schools in Malaysia and found that there was a significant difference between the performance of male and female students. The findings were contrary to previous studies that point out that female learners perform better than males. In this study, male students in these four boarding schools obtained better grades in English. They argue that these results have to do with the cultural view of language as feminine or masculine. While in some studies, female students performed better than males or vice versa, all studies suggest that gender roles are attached to social situations.

Another factor that has been connected to language achievement is socio-economic status. In fact, class and socio-economic status have been described as factors influencing language learning. In a study by Cheng, Yunus and Mohamad (2016), learners in the rural area performed relatively lower than those studying in urban schools. They specifically explored the differences between a group of students who excelled at learning English and another group with poor results. The latter group did not only receive more support from parents at home but also showed a need to use English. Then, those students who obtained better performance had greater parents' involvement in school tasks and came from families with higher economic status and education background. Similarly, Karthigeyan and Nirmala (2012) found that secondary school participants' performance of English was higher for those studying in urban areas. Moreover, Bidin and Jusoff's (2009) findings indicate that those children whose parents receive a higher income, achieve better grades in English in comparison to students of low-income parents. Also, Roy (2014) studied the cause behind Bangladeshi learners' low performance of English in elementary school in comparison to other subjects. Qualitative findings showed that among the reasons for such low performance are that English is used among educated people and that it is a difficult language to learn.

Additionally, studies also show that socioeconomic status has an impact on tertiary education. Ariani and Ghafournia's (2016) study with Iranian university students found that upper middle-class students had a positive relationship with language learning while lower-middle-class students' performance was not satisfactory. Those from lower socio-economic status had the lowest performance. Another study in Chile (Kormos \& Kiddle, 2013) shows that lower social classes rarely need English for professional purposes and do not have access to educational resources. A more recent study by Mansoorian and Razmjoo (2021) found no significant difference between the test achievement scores of students from public and private schools, but complementary 
results revealed that the school background partially influenced students' language achievement. These findings do not only suggest the importance of exploring the reasons students perform low in English in primary education and other levels of education, but also the relationship that performance has with the social context, in this case with external factors such as gender or socio-economic status. The socioeconomic status cannot be separated from the person; this context becomes part of the student (Ushioda, 2009).

\subsection{Learning English in Mexico}

As mentioned earlier, context greatly shapes students' language performance. The studies described earlier show that gender and socio-economic status are connected to performance results. For this reason, the following studies describe the current situation with regard to English language performance in Mexico. A study that involved 4, 727 lower secondary school students shows that a great percentage (97\%) of students do not fulfill the level of English (B1) recommended by the Ministry of Education (Székely, O'Donoghue \& Pérez, 2015). Similarly, other studies reveal similar results. González, Vivaldo and Castillo (2004) performed a study in a university in Mexico City. The participants answered a proficiency test, but only about $10 \%$ of the sample students obtained satisfactory results. Other studies also highlight Mexico's low language competency in English (Borjian, 2008; Borjian, 2015; Borjian \& Padilla, 2010; Despagne, 2010; Davies, 2009; Sierra \& Padilla, 2003) even though English is taught in high school (2 - 3 years). Many students who want to pursue higher studies might not even reach A1 established in the CEFR.

It has further been pointed out that social context is connected to language test performance, but there is a lack of studies in Mexico making this connection. To illustrate, Mexico's population who speak English is concentrated in urban parts of Mexico. Similarly, in the northern part and central Mexico more people speak English compared to people who live in the southern states since most of the business industries are concentrated in these areas. Yet, tourist places in the south of Mexico also have residents or workers who speak English. Basically, speakers of English are concentrated in cities in terms of business and travel. Even the web informs English speakers, who would like to visit Mexico, that English is not prevalent out of the famous touristic spots or as the web states, "... the richer and more privileged have far more chance of being able to speak decent English, as opposed to the poor or working-class who do not have access to the same resources." (Howwidelyspoken.com, 2021).

Studies regarding socioeconomic status in Mexico indicate that those students with higher status obtain better language learning results. For instance, Heredia and Rubio (2015) analyzed the unequal situation of learning English in Mexico and showed that those students with higher income from a prestigious Mexican university diverse in socioeconomic terms, achieved better results in a diagnostic test. In fact, the students who had traveled abroad belonged to this group of students. As López-Gopar and Sughrua (2014, p.108) mention "International travel is primarily typical of upper-middle-class families in Mexico". In a different study, Davies (2009) reviewed the situation of language performance statistics of Mexican and private universities and found that private universities outweigh state universities in terms of learning English. Additionally, a study performed by the British Council (2015) shows that the percentage of English language speakers is larger for central and northern Mexico and that socioeconomic status is also linked to those who speak English. The picture in this context as in other Latin-American countries, suggests that people who have knowledge of English also have an economic advantage over those who do not actually speak it.

As the context is important, this study took place in a public university located in Campeche, a southeastern state of Mexico. Even within the same country, there might be clear differences among the population that speaks English. The proximity to countries where English is spoken, or constant business transactions performed in English provide alternative scenarios to use the foreign language. This region of the country has been overlooked for the teaching-learning of English as most of the studies on language performance have been performed in the central and northern parts of Mexico. Following this line, this study focuses on the following research questions:

1) What is the first-year university students' language performance on a diagnostic exam of English at a Mexican public university?

2) How do contextual factors, such as gender and public and private high school (socio-economic status), contribute to students' English test performance?

\section{Methodology}

This research took place in a public university in southeast Mexico, and forms part of a larger study. The university authorities granted permission to analyze students' scores on the diagnostic institutional exam of English of first year university students. The first step in this quantitative study consisted of analyzing the exam content and evaluation form. Descriptive statistics provides students' performance on the institutional exam. Similarly, independent sample t-tests explored the significance of the type of high school education related to test performance. This approach provides objective data for analysis and generalization. 


\subsection{Instrument: The diagnostic test}

There was one instrument used to collect data: The institutional evaluation of English. The exam is an institutional measure of evaluation that has been designed by the teachers, who are part of the English language academy, at the university language center. More than 25 trained-certified English teachers evaluated the exam which has provided content validity to the test. This multiple-choice test is used every year to place first year students in the corresponding English course. It includes a listening comprehension section with 20 items, a reading comprehension section with 20 items, and a grammar and vocabulary section with 120 items. The participants had 95 minutes to respond. The listening section lasted 15 minutes, the reading section lasted 20 minutes and the last section lasted 60 minutes. The exam items are based upon the content of the general English courses that are taught at the language center and are based on the Common European Framework of Reference for Languages (CEFR). Every university student should graduate holding at least a B1- as level of English proficiency.

\subsection{Participants}

Prior consent of participation in the study, the university provided students' information regarding the university program of study, place of origin, type of high school (public or private). The total sample number of students who answered the exam was 882. The average age for the participants was 18. There were 486 females and 396 males. In addition, most students mentioned Spanish as their native language; only a couple of students mentioned indigenous languages. Most came from the southeast region of Mexico. Students mostly (73\%) studied in a public high school while $13.7 \%$ studied in a private school - most high schools in Mexico include three years of studying English. A small percentage (1.2\%) has either visited or lived in a foreign country. All students are first-year university students.

\subsection{Procedure and data Analysis}

The information regarding the participants' test results and background was recorded in a database using students' identification numbers. All analyses were carried out using SPSS version 21. For instance, descriptive statistics was performed to corroborate data entry and to calculate students' overall test results. Independent sample T-tests were carried out to find the contextual factors related to performance.

\section{Results and Discussion}

In order to answer the first research question i.e., the level of English that students hold in an institutional exam of English, first descriptive statistics such as mean, median, mode and standard deviation are presented. Later, results from statistical analysis such as independent sample t-tests are displayed to analyze the variables that contribute to the prediction of test performance.

\section{Test language performance}

The results of the exam are presented per section as in the test itself: 1) listening, 2) reading, and the grammar and vocabulary section. As mentioned in the methodology section, the total number of items in the test is 160 . The minimum and maximum scores obtained in each section are displayed in Table 1.

Table 1: Descriptive Statistics of Test Results

\begin{tabular}{llllllll}
\hline Sections & N & $\begin{array}{l}\text { Minimum } \\
\text { score }\end{array}$ & $\begin{array}{l}\text { Maximum } \\
\text { score }\end{array}$ & Mean & Median & Mode & $\begin{array}{l}\text { Std. } \\
\text { Deviation }\end{array}$ \\
& & & & & & \\
\hline Listening & 882 & 0 & 19 & 7.55 & 7 & 6 & 3.60 \\
Reading & 882 & 0 & 20 & 7.72 & 7 & 6 & 4.44 \\
Grammar/Vocab & 882 & 4 & 113 & 40.16 & 35 & 31 & 18.04 \\
\hline Total & 882 & 4 & 152 & 54.43 & 49 & $43^{\text {a }}$ & 26.08 \\
\hline
\end{tabular}

As Table 1 shows, there were students who did not obtain any points in the listening section, which included 20 questions. Similarly, the reading section also obtained 0 as the minimum score, while the highest was 20 . The mean scores for both the listening and reading sections indicate that these skills might be problematic for students. However, the low results were not exclusive for the reading and listening skills. Results in the grammar and vocabulary section were also low. Contrary to the previous categories, the minimum score was 4 . Yet this was a section of 120 items. Results show that the test mean score is 40.16, indicating that students do not even achieve half of the exam points. Also, in the section on grammar and vocabulary the standard deviation is higher than in the other sections. This implies that the groups being evaluated hold significant differences in this language domain. 
Table 2: Test Scores according to Performance Category

\begin{tabular}{llll}
\hline Test Score Range & Test score & N. of students & Percent \\
160 points & Scale $1-100$ & & \\
& & & \\
\hline $0-79$ & $1.8-49$ & 752 & 85 \\
$80-111$ & $50-69$ & 84 & 10 \\
$112-160$ & $70-93.7$ & 46 & 5 \\
\hline Total & & 882 & $100 \%$ \\
\hline
\end{tabular}

Table 2 illustrates the students' scores categorized into three groups considering the possible total score, which is 160 . This score was converted to a scale of 1 to 100 as the minimum passing grade for a course in the institution is $70 / 100$. In other words, the first two categories indicate failing scores based on the institution's evaluation parameters. As can be seen, most students belong to the first category, not even 50 points. A smaller number of students scored over 50 but below 70 , also indicating a non-satisfactory score. Only $5 \%$ of students scored over 70 points. In other words, out of 882 students only 46 obtained a passing score.

The institutional evaluation of English provides results that are essential not only to the institution to make decisions regarding the appropriate instructional settings for the students to learn English at the university, but also to perform statistical analysis which aims to answer which background variables are related to language performance. Then, it became necessary to explore the possible social factors that contribute to these results on the test. Yet, results from background variables such as age, place of origin, language, experience abroad was not further explored as results were not relevant to be contrasted. For instance, average age was 18, most students were from the southeast region, only two people mentioned a different mother tongue from Spanish, and only a small percentage (1.2\%) had experienced traveling or living abroad. The two salient variables were gender and type of school, and they were further explored.

\subsection{Gender and type of high school}

As mentioned earlier, the total number of participants was 882. From this sample, there were 486 women and 396 men. The distribution of participants according to gender and test performance is displayed in Table 3.

Table 3: Distribution of Participants by Test Performance and Gender

\begin{tabular}{lllll}
\hline $\begin{array}{l}\text { Test Score Range } \\
160 \text { points }\end{array}$ & $\begin{array}{l}\text { Test score } \\
\text { Scale 1-100 }\end{array}$ & Female & Male & \\
& & & & \\
\hline $0-79$ & $1.8-49$ & 416 & 336 & 752 \\
$80-111$ & $50-69$ & 44 & 40 & 84 \\
$112-150$ & $70-93.7$ & 26 & 20 & 46 \\
\hline Total & & 486 & 396 & 882
\end{tabular}

Most students obtained a low score on the test. In other words, the test results are very similar for females and males in all the skills categories. To explore the statistical relationship between the English test scores and gender and type of high school, independent sample t-tests were conducted. 
Table 4: Female and male mean scores

\begin{tabular}{llll}
\hline Group & N. of students & Mean score & SD \\
\hline Female & 486 & 55.22 & 24.77 \\
Male & 396 & 55.62 & 24.80 \\
\hline
\end{tabular}

The results from the independent sample t-test for the English test scores of males and females show there was no significant difference found in scores for males $(M=55.62, S D=24.80)$ and females $(M=55.22, S D=24.77 ; t(880)=-.24$. The magnitude of the differences in the means (mean difference $=-.40,95 \% \mathrm{Cl}-3.69$ to 2.89 ) was very small. The significance value was .81 .

Table 5: Public and private school students' scores

\begin{tabular}{llll}
\hline Group & N. of students & Mean score & SD \\
\hline Public high school & 648 & 53.67 & 23.27 \\
Private high school & 234 & 67.07 & 28.79 \\
\hline
\end{tabular}

An independent sample t-test was also performed to compare the students' test scores from public and private high schools. There was a significant difference found in scores for public high schools $(M=53.67, S D=23.27)$ and private high schools $(M=67.07, S D=28.79 ; t(150)=-4.8$. The significance value is .00 indicating a significant difference on the dependent variable. Therefore, those students who studied at private high schools obtained a higher score.

The English exam results exemplify the level of English students hold by the start of tertiary education. Scores on all three skills sections of the test are low. The mean scores, as well as the standard deviations, indicate that most students' language performance is below average. Nevertheless, while gender is not an indicator of students' performance on the test, the type of high school education is a predictor of test results.

In general, the test results agree with different testing studies performed in Mexico (Borjian, 2008; Borjian, 2015; Borjian \& Padilla, 2010; Despagne, 2010; Davies, 2009; González, et al, 2004; Sierra \& Padilla, 2003). In fact, from 88 countries around the world, Mexico holds the $57^{\text {th }}$ position and the $9^{\text {th }}$ out of 17 countries in Latin America (EF English Proficiency Index, 2019). The Mexican state, Campeche, where the study took place, seems to be among the regions with the lowest competence of English (British Council, 2015; EF English Proficiency Index, 2020). Students' low level of English becomes a problem for university students in Latin-American universities as they require a minimum score in an international test for students to obtain their diploma (Abreus \& Hernandez, 2016; British Council, 2015). Based on test results, most students in this study are placed in Level A courses, which means they do not even reach basic levels of English based on the CEFR. Additionally, it is very unlikely that students use the standardized examination options (e.g. TOEFL, IELTS) the university requires to exempt the English courses. As a result, the university does not only face the problem of accommodating a great number of students on basic levels of English but also the responsibility to take students from basically "no English" to B2 (CEFR).

Although the relationship between gender and language performance has been studied in different contexts, and in those studies, women generally achieve better results than men (Karthigeyan \& Nirmala, 2012; Główka, 2014; Murphy, 2010), the results of this research show evidence that both women and men's performance achieved low test results. This can be partly explained as most schools in Mexico are mixed gender. Yet, it is necessary to further explore the gender differences about learning English in the classroom as these results are based only on test performance. All in all, test performance results do not indicate a difference based on gender, but it does indicate a problem of inequity related to social status.

Social inequality might be a continuous part of the problem of learning English in Mexico. Knowing English has become a symbol of "high status". To illustrate, many Mexicans say they do not know English because of a lack of money (Heredia \& Rubio, 2015). Money gives access to a better school; money gives access to pay extra English lessons.

The results of this study go in line with other studies performed in Mexico (Sayer, 2018; Cheng, Yunus \& Mohamad, 2016; Ariani and Ghafournia, 2016) and around the world. In general, receiving education from a private school suggests a higher socioeconomic status. This position allows a language learner to experience English differently from a learner of a lower economy position. This type of learner can afford certain study material or equipment, has easy access to information technologies or can travel abroad. There are clear differences in the use of English in rural and urban areas (Karthigeyan \& Nirmala, 2012, 2014; 
Cheng, Yunus \& Mohamad, 2016; Sayer, 2018). Opportunities cannot be equal for people who have access to more resources such as technology, travel, and better living conditions. Studies performed in Mexico have found that students whose parents receive higher incomes perform better in English (González et al., 2004; Heredia \& Rubio, 2015; British Council, 2015). The results of this study coincide with Ariani and Ghafournia's (2016) study, as university students from the upper-middle class had a positive relationship with learning English; yet, it has different results from the study of Mansoorian and Razmjoo (2021), who found no significant differences between public and private education students' test results. Although in this study socioeconomic status was not explored per se, it is intrinsically related to receiving education from a private institution. Private institutions charge fees in addition to requiring supplementary study material at an extra cost from parents. This is not affordable for low-income families.

\section{Conclusion}

As a sum, it is important to continue performing studies on tertiary education that is linked to the previous stage as it is high school. Studies that show results on test performance and contextual factors are useful to reflect on the teaching practices at university. Although this study did not show a significant difference in gender, other studies exploring this factor have shown that there are important differences in terms of choice of learning strategies and linguistics skills between genders. Moreover, this study shows there is a difference between public and private students' test scores. Although this study does not focus on socio-economic status, it points out the difference in scores between these groups of students. Therefore, it is important to explore the Mexican classroom to know the current practices in both types of high schools. On the one hand, methodology in English language teaching might be among the first areas of research since there are studies that indicate differences between public and private schools. One of these differences is the use of more teaching techniques and higher motivation from private school teachers (Alipour, 2018; Pervaiz, Rana, Bashir, and Batool, 2021). On the other hand, studies performed in public schools (Basurto Santos \& Weathers, 2016; Castro-García, 2020) show that these students are at a clear disadvantage when learning English and have a shortage of classroom resources.

Therefore, public universities uphold a great responsibility to provide the learning experiences that students have not received before and need (Quijano-Zavala, Martínez Ortiz and May-Meléndez, 2019). Competent and brilliant individuals might miss opportunities for not being capable of communicating in English. Therefore, even though the economic gap cannot be reduced immediately as it is a more complex social factor, universities have the responsibility to provide equal education for students to train professionals with competent skills in English, who are demanded in the globalized world.

Funding: "This research received no external funding".

Acknowledgments: We are particularly grateful for the participation of university students in this study. I would also like to thank the university authorities for the access to the institution facilities.

Conflicts of Interest: "The authors declare no conflict of interest."

\section{References}

[1] Abreus González, A. \& Hernández Castro, P. (2016). Nuevos retos para la enseñanza del inglés en la universidad. Ecuatoriana actual. Revista Electrónica Formación y Calidad Educativa, 4(3), 121-130.

[2] Alipour, S. (2018). Comparison of private-institute and public-school English teachers' motivation towards teaching English in Iran. Cypriot Journal of Educational Sciences 13(4), 631-644. https://doi.org/10.18844/cjes.v13i4.3600

[3] Ariani, M. G. \& Ghafournia, N. (2016). The relationship between socio-economic status, general language learning outcome, and beliefs about language learning. International Education studies, 9(2), 89-98.

[4] Ariyani, F., Rusminto, N. E., \& Setiyadi, A. B. (2018). Language Learning Strategies Based On Gender. Theory and Practice in Language Studies, 8(11), 15-24. https://doi.org.10.17507/tpls.0811.19

[5] Basurto Santos, N. M., \& Gregory Weathers, J. R. (2016). EFL in public schools in Mexico: Dancing around the ring?. HOW, 23(1), 68-84. http://dx.doi.org/10.19183/how.23.1.297.

[6] Bidin, S. \& Jusoff, K.(2009). The Influence of Gender and Social Economic Status on Boarding School Students' English Language Performance. Canadian Social Science, 5(5), 41-47

[7] Borjian, A. (2008). Teaching English in Public Elementary Schools in Mexico: From Theory to Practice, Report to Fulbright.

[8] Borjian, A. (2015). Learning English in Mexico. The CATESOL Journal, 27(1),163-173.

[9] Borjian, I. \& Padilla, A. (2010). How U.S. teachers can meet the needs of immigrant students. The Urban Review, 42, 316-328.

[10] British Council (2015). English in Mexico: An examination of policy, perceptions and influencing factors. Mexico: British Council, Education Intelligence. 
[11] Bumble's The Beehive (January 26, 2018). Lost in translation: the different ways men and women talk about troubles. Retrieved August 28, 2021 from https://thebeehive.bumble.com/bumbleblog/troubles-talk-dont-tell-me-what-to-do

[12] Castro-García, D. (2020). Public school students at a clear disadvantage in English language vocabulary production. Káñina, 44(2), 6994. https://dx.doi.org/10.15517/rk.v44i2.44053

[13] Cheng, L. Yunus, M. \& Mohamad, M. (2016). Issues contributing to low performance of English in a national school in Song, Sarawak. Proceedings of ICECRS, 1, 499-510. httpp://dx.doi.org/10.21070/picecers.vlil.519

[14] Davies, P. (2009). Strategic Management of ELT in Public Educational Systems: Trying to reduce Failure, Increase Success. TESL- EJ, 13, 1-22.

[15] Dearden, J. (2014). English as a medium of instruction: A growing global phenomenon. British council: UK

[16] Despagne, C. (2010). The Difficulties of Learning English: Perceptions and Attitudes in Mexico. Canadian and International Education / Education canadienne et internationale, 39(2), 55-74.

[17] EF English Proficiency Index (2019). Latin America. Retrieved July 1, 2019 from https://www.ef.com/wwen/epi/regions/latinamerica/mexico/

[18] EF English Proficiency Index (2020). Latin America. Retrieved March, 12, 2020, from https://www.ef.com/wwen/epi/regions/latin-america/

[19] Ellis, R. (1994). The Study of Second Language Acquisition. Oxford: Oxford University Press.

[20] Główka, D. (2014). The impact of gender on attainment in learning English as a foreign language. Studies in second language learning and teaching, 4(4) 617-635. https://doi.org/10.14746/ssllt.2014.4.4.3

[21] González Robles, R. O., Vivaldo Lima, J. \& Castillo Morales, A. (2004). Competencia Lingüística en Inglés de Estudiantes de Primer Ingreso a Instituciones de Educación Superior del Área Metropolitana de la Ciudad de México. México-UAM Iztapalapa: ANUIES.

[22] Heredia, B. \& Rubio, D. (2015). English and social inequity in Mexico. In J. L. O'Donoghue (Ed.), Sorry: Learning English in Mexico (pp. 27-37). México, D.F.:Mexicanos Primero.

[23] Howwidelyspoken.com (2021). How widely spoken is English in Mexico? Retrieved August 29, 2021,from https://howwidelyspoken.com/how-widely-spoken-english-mexico/

[24] Karthigeyan, K. \& Nirmala, K. (2012). Academic Achievement in English: An analysis through gender lens. MIER Journal of Educational Studies, Trends \& Practices, 2, 144-157.

[25] Kormos, J. \& Kiddle, T. (2013). The role of socio-economic factors in motivation to learn English as a foreign language: The case of Chile. System 41, $399-412$.

[26] López-Gopar, M. \& Sughrua, W. (2014). Social class in English language education in Oaxaca, Mexico. Journal of language, identity and education, 13,104-110

[27] Mahmud, M. (2010). Language and gender in English language teaching. TEFLIN Journal, 21 (2), 172 -185.

[28] Mansoorian, S. \& Razmjoo, S. (2021). The Impact of Socio-Economic Status (SES) on the Iranian EFL Learners' Identity Processing Styles and Language Achievement. Journal of English Language Teaching and Learning, 13(27), 295-331. doi: 10.22034/elt.2021.41027.2276

[29] Murphy, B. (2010). Foreign language learning in Irish second level schools: Gender very much on the agenda. Irish Educational Studies, 29, 81-95.

[30] Namaziandost, E. Abedi, P. \& Nasri (2019). The role of gender in the accuracy and fluency of Iranian UpperIntermediate EFL learners' L2 Oral Productions. Journal of Applied Linguistics and Language Research, 6 (3), pp. 1-14.

[31] Pervaiz, A. Rana, A. M. K., Bashir, I. \& Batool, N. (2021). Exploring the writing Techniques of ELT Practioners in Private and Public Schools. International Journal of innovation, creativity and change, 15, 3 823-838.

[32] Quijano-Zavala, G.G., Martínez-Ortiz, M.L. \& May-Meléndez, R.A. Aprendizaje del Inglés: Experiencia Previa, Autoevaluación Y Expectativa en la Educación Superior. REFCalE: Revista Electrónica Formación y Calidad Educativa, 7, 87-102

[33] Rind, I. A. (2015). Gender identities and female students' learning experiences in studying English as second language at a Pakistani University. Cogent Education, 2, 3-11. http://dx.doi.org/10.1080/2331186X.2015.1115574

[34] Roy, G. (2014). Causes behind poor performance in English of Bangladeshi Primary students. NELTA $19^{\text {th }}$ International Conferences, Kathmandu, Nepal, March 1, 2014. Retrieved from https://www.researchgate.net/publication/269808543 NELTA2014 Goutam

[35] Sayer, P. (2018). Does English really open doors? Social class and English teaching in public primary schools in Mexico, System, 73, 58-70.

[36] Sierra, A.M. \& Padilla, A.M. (2003). United States' hegemony and purposes for learning English in Mexico. In P. R. Terborg (Ed.), Language:Issues of inequality (pp. 215-234). Mexico D.F.: University of Mexico Press.

[37] Székely, M., O'Donoghue, J.L. \& Pérez, H. (2015). The state of English language learning in Mexico. In J. L. O'Donoghue (Ed.), Sorry, Learning English in Mexico (pp. 83-96). Mexico: Mexicanos Primero.

[38] Tannen, D. (1990). You just don't understand: Women and men in conversation. London: Virago.

[39] Ur, P. (2012). A course in English language teaching. Cambridge: Cambridge University Press.

[40] Ushioda, E. (2009). A person-in-context relational view of emergent motivation, self and identity. In Z. D. \&. E. Ushioda (Eds.), Motivation, Language and Identity (pp. 215-228). Bristol: Multilingual Matters. 